\title{
The Value of Gender Equality in EU-Asian Trade Policy: an assessment of the EU's ability to implement its own legal obligations
}

\section{Paper presented at UACES 2-4 September 2013}

\author{
Maria Garcia, University of Bath \\ Annick Masselot, University of Canterbury
}

"For money, you would sell your soul."

Sophocles, Antigone

\section{Introduction}

This chapter aims to assess the tensions and contradictions that exist between the European Union's (EU) internal and international legal obligations to achieve gender equality in all its activities, and its engagement in the global competitive economy. The context of the economic relations negotiations between the EU and the Asian region provides an excellent vantage point to highlight the significant difficulties in diffusing gender norms through the medium of trade and the consequences of not doing so.

The EU promotes itself as a world leader in democratic values (including gender equality), international climate change and environmental negotiations and has ambitions to lead the global debate on sustainable development (see inter alia Manners 2002, 2008; Aggestam 2008; Lightfoot \& Burchell 2005; Vogler \& Stephen 2007; Allwood et al. 2013; Bain \& Masselot 2013). Using discourse and legal analysis, this chapter demonstrates that in all these areas and "as a policy entrepreneur in the field of gender" (David and Guerrina 2013, 53), the EU raises the expectation of changes in diffusing these "universal values" (preamble of the Lisbon Treaty). However, despite the existence of legal obligations and much political rhetoric, it is argued that the EU succumbs to internal and external resistance to the promotion of fundamental values. Such values as gender equality appear to clash with the EU's desire and interest to foster good economic relations with key rising markets. The EU economic relations with Asia have focussed almost exclusively on the promotion and facilitation of trade and investment to enhance economic growth, through the negotiation of far-reaching trade agreements and have left virtually no space for facilitating the inclusion of 
a gender dimension. Ultimately, this benefits EU-Asian trade, at the expense of promotion of core EU values such as gender equality. This paper argues that the lack of reflexivity has implications for the EU's external actions and its own internal order.

By way of disclaimer, it is appropriate to note here that this chapter is not intended to serve as "testing grounds for the universalization of western social sciences" (Mitchell 2003, 98). While acknowledging the heterogeneity of women across the Asian region, the chapter recognises nevertheless that gender as an analytical category has universal relevance. Women as a group are more vulnerable to poverty because of unequal distribution in income and assets, access to credits, business services, control over the income and structural gender market biased (UN ESCAP 2013). It is also recognised that "gender" should not be understood as "women" but that women are part of "gender" (Derichs 2013, 126). Gender is a relational term, which includes men and women. In this paper "gender" points to a set of learned qualities and behaviours influenced by such factors as education or economics and which is expected as a role from men and women .

This chapter starts by providing a critical assessment of the legal background to the EU's obligations in the field of gender equality (part 1). It then points towards the EU official policy on trade, which reveals a systemic failure to implement gender equality norms into this aspect of its foreign policy (part 2). Against this backdrop, the chapter investigates the impacts of the lack of gender perspective on trade negotiations in the Asian region (part 3). The final section of this chapter addresses the external resistance to EU (weak) attempts at linking its trade policy with broader values including social and gender rights. It assesses critically these external barriers specifically related to the Asian region and the consequences for the EU's relationship with that region of the world as well as for the EU internal policy (part 4).

\section{The EU's obligations and commitments to gender equality in external relations}

The EU has entrenched the principle of "gender equality as one of the central missions and activities of the Union" (Bell 2011, 629) and one of its fundamental values (KoukoulisSpiliotopoulos 2008). Indeed, Article 2 of the Treaty on European Union (TEU) proclaims that equality is one of the values on which the Union is founded. As such, the EU has an obligation to take into account the principle of gender equality when planning and enacting 
any types of legislation. This so-called obligation of gender mainstreaming (Pollack and Hafner-Burton 2000) is now contained in Article 8 of the Treaty on the Functioning of the European Union (TFEU) and provides that "[i]n all its activities, the Union shall aim to eliminate inequalities, and to promote equality, between men and women." Thus, a gender dimension should be incorporated in every single area of the EU's activity (including trade).

The obligation to achieve gender equality has further been confirmed as a constitutional fundamental right legally guaranteed by Article 23 of the EU Charter of Fundamental Rights (the Charter), which provides that "[e]quality between women and men must be ensured in all areas, including employment, work and pay. The principle of equality shall not prevent the maintenance or adoption of measures providing for specific advantages in favour of the under-represented sex."

The constitutionalisation of gender equality law has also triggered its externalisation. The expansion of the scope of EU gender equality under the EU Treaty has had international impacts. Indeed, the Treaty gives to the EU competences relating to freedom, security and justice to which equality between women and men apply. Article 21(1) of the TEU outlines clearly that the EU's Common Foreign Policy and Security Policy "shall be guided by the principles which have inspired its own creation, development and enlargement, and which it seeks to advance in the wider world: democracy, the rule of law, the universality and indivisibility of human rights and fundamental freedoms, respect for human dignity, the principles of equality and solidarity, and respect for the principles of the United Nations Charter and international law" (emphasis added). In addition, the European Commission's Roadmap for Equality between Women and Men (2006 - 2010) and the Strategy for Equality between Women and Men (2010-15) cover both internal and external EU policies with a view to improving the coherence between these two pillars. The Strategy provides in particular that "equality is one of five values on which the Union is founded. The Union is bound to strive for equality between women and men in all its activities" (European Commission 2010). In relation to gender equality in external actions, the Strategy states that "EU policy on the promotion of gender equality within the EU is closely linked to the work undertaken by the Union in third countries. Through all relevant policies under its external action, the EU can exercise significant influence in fostering gender equality and women's empowerment worldwide." It further adds that the "EU will continue to use its development policies to promote gender equality and women's empowerment." As a result, any international action 
undertaken by the EU must be guided by the principle of EU gender equality and should be included in the EU's relationship with third countries. The highest law of the EU has therefore clearly established a strong commitment to a reflective ${ }^{1}$ process involving consideration of gender norms within and outside the boundaries of its territory in all policy areas.

At the international level, the EU's most powerful tools for normative extension have been development cooperation and trade, both of which are potentially areas where the EU's powerful normative action could be use to their fullest capacities in relation to the acceptance and implementation of EU values, and engagement with multilateral bodies. The EU has been relatively successful in incorporating the promotion of gender equality norms into some of its development policies, as for instance in the context of the United Nations' Millennium Development Goals and the co-operation and development in the African, Caribbean and Pacific regions (Allwood 2013, Arts 2006). By contrast, the EU-Asia co-operation and development policy was, from the outset, directly linked to the growing economic and political power of the Asian region (European Commission 1994, 2001). It has left little space for influence of general EU policy on co-operation and development in particular over the commitment to gender equality and gender mainstreaming (Masselot 2013).

Unfortunately, the tension between the EU gender equality agenda and competing economic interests is even more evident in the EU's trade policy towards the region. As Asian consumers gain purchasing power, Europe has become more concerned with negotiating access to these emerging markets. Negotiations for comprehensive free trade agreements (FTA) between the EU and Asian states commenced in 2007 and are accompanied by the negotiation of overarching Framework Agreements (FA) that establish the legal basis of the relationship. FAs incorporate many of the EU's normative concerns, including sustainability, nuclear non-proliferation, counter-terrorism cooperation, support for multilateral organisations, yet they do so in non-binding terms (Horn at al. 2010). More importantly, gender equality is conspicuous for its absence in the EU's trade policy, as subsequent sections reveal, despite it being an EU value, and despite DG Trade's acknowledgement that "as we pursue social justice and cohesion at home, ${ }^{2}$ we should also seek to promote our values,

\footnotetext{
${ }^{1}$ Reflexivity here means that there is a state of consistency between the internal and the external EU actions (David and Guerrina 2013).

2 Acknowledging the unequal effects of trade liberalisation, 'Global Europe' establishes the European
} 
including social and environmental standards and cultural diversity, around the world" (European Commission 2006, 5).

The existence of tension between market needs and equal rights is not new and therefore it is not surprising to find the same struggle in EU-Asian trade relations. Commitment to equality has always been entangled with economic and market based considerations (Holskyns 1996). In reality, the neo-liberal project and economic considerations have often taken precedence over fundamental rights (MacRea 2013) despite legal statement to the contrary. ${ }^{3}$ However, what we witness in the context of trade negotiations with the Asian region is the complete abdication of the EU in engaging with (gender) equality in order to complete the economic project of market liberalisation, open competition and free market. Arguably this is not merely an issue of competing policies areas but it can be construed that the EU is not acting within its legal constrains and boundaries.

\section{Genderless Trade Policy}

As the EU's oldest external policy, trade policy has always served economic and broader foreign policy objectives (Baldwin 2006). On the one hand, the policy has always had a mandate to open markets for European business: ${ }^{4}$

By establishing a customs union [...] the Member States intend to contribute, in

Globalisation Fund to help stem some of the negative effects, and 'Trade, Growth and World Affairs' aims to extend and simplify the fund.

3 Indeed in C-270/97 Deutsche Post v Sievers \& Schrage [2000] ECR I-929, the Court of Justice held unambiguously that the economic aims are now only secondary to the social aims, therefore providing a clear ideological motivation for the application of European Union law. See also Case 149/77 Defrennes (no. 3) [1978] ECR 1365, paragraphs 26 and 27; Joined Cases 75/82 and 117/82 Razzouk and Beydoun v Commission, [1984] ECR 1509, paragraph 16, and Case C-13/94 P. v S. and Cornwall County Council [1996] ECR I-2143, paragraph 19; (Arnull 1990, Docksey 1991).

${ }^{4}$ Studies of the EU's trade policy have highlighted its inherent bias towards free trade and liberalisation. Proponents of the collusive delegation thesis argue this derives from the institutional arrangement whereby member states transferred EU trade policy to the European Commission, creating a principal-agent relationship (Elsig 2007), which isolated the Commission from the protectionist impulses of domestic economic sectors (Meunier and Nicolaidis 1999, Meunier 2000). Others argue the policies result from competition amongst interest groups and effective lobbying of the European Commission and member states (De Bieve and Dür 2005, Dür 2008). Focusing on effective lobbying, the Corporate Europe Observatory thinktank based in Brussels, (see Eberhardt and Kumar 2010) maintains that the business lobby's access to the European Commission and other institutional actors is reflected in a liberal trade policy focused on opening markets abroad for services and investment, which downplays the possible negative effects of trade liberalisation. The complex interactions between principals, agents, interest groups and the folding of foreign policy aims into trade policy have led Sophie Meunier and Kalypso Nicolaidis (2006) to describe the EU as a "conflicted trade power". 
conformity with the common interest, to the harmonious development of world trade, the progressive abolition of restrictions on international exchanges and the lowering of customs barriers (Article 110 of the Treaty founding the European Economic Community, 1957).

The emphasis on liberalisation represents a material interest-driven policy, and an institutional ideational belief in the developmental power of trade (see Garcia 2013). Particularly under the stewardship of Trade Commissioner Pascal Lamy (1999-2004), the EU's trade policy was discursively linked to its development policy goals, and attempts were made to articulate Lamy's 'managed globalisation' concept, which subordinated trade policy to multilateralism, sustainability and social justice (Meunier 2007) at the WTO (see Abdewal \& Meunier 2010). On the other hand, being the EU's earliest and most 'communitarised' external policy, trade policy was also used to pursue other foreign policy aims (Smith 2006, Baldwin 2006), inter alia democratisation, regional integration or stability, albeit with mixed results (see Garcia 2012, Youngs 2004).

Commitments to external norm promotion are reflected in DG Trade's policy, even in the liberal and competitiveness driven post 'Global Europe' policies, which acknowledge "we are paying systematic attention to coherence with development policies, such as poverty eradication and insisting on the promotion in trade negotiations of sustainable development (i.e. decent work, labour standards and environmental protection)" (European Commission $2010,4)^{5}$

Normative promotion in the EU's trade policy revolves around the incorporation of a democracy clause in FAs, which makes the FTA contingent on respect of human rights and the rule of law. Recent FTAs also seek to externalise the concept of sustainability through the incorporation of social and environmental sustainability clauses. Social sustainability in terms of EU trade policy is defined in narrow terms as referring to 'decent work' and to upholding the core conventions of the International Labour Organisation (ILO). Other social issues such as poverty reduction, health and education matters or discrimination are absent from the scope of action of DG Trade and its frame of reference, even though some of its actions in the field of trade could impact upon these matters (e.g. liberalisation of health services in FTAs).

\footnotetext{
${ }^{5}$ In 2006 Commissioner Peter Mandelson published the 'Global Europe' trade policy which focuses on market opening, especially in emerging markets, pursuing comprehensive 'deep' trade agreements including public procurement, services, competition policy and intellectual property rights, and is driven overall by a concern with "competitiveness" (Woolcock 2007) Commissioner Karel De Gucht's 2010 'Trade, Growth and World Affairs' trade strategy follows the same lines.
} 
DG Trade's social focus, thus, lies in the field of basic workers' rights and basic labour standards. Perhaps not surprisingly, of the EU's values an normative objectives, breach of these abroad could result in trade advantages for partners as they can realise lower labour costs, and in a worst case scenario social dumping, which could lead to downward pressures on EU internal employment and social policies.

Not surprisingly, the DGs most closely engaged with the Neo-liberal economic project are the least likely to implement gender mainstreaming strategy or to recognise that their policy and activities are in any way gendered (MacRae 2013). DG Trade's limited interpretation of social sustainability translates into policies that fail to explicitly incorporate some of the EU's mandated values. EU trade documents, for instance, lack any explicit mention to gender mainstreaming or to equality, unlike the EU's development policy. In one of her studies, Holskyns notes that DG Trade has no time, little expertise to do work on gender and that despite the existence of mainstreaming programmes, officials did not believe that they had any responsibility in addressing gender (2004, 15). Debusscher and True (2008) have highlighted the absence of systematic gender mainstreaming in DG Trade, and the lack of a dedicated gender officer, which other external action DGs have had. In particular DG Development would appear to have made the greatest head-way in gender mainstreaming, in part Debusscher and True (2008) argue as a result of the lobbying of action networks (e.g. Women in Development Europe WIDE). Through its collaboration with UN Women, the EU has developed training materials for gender considerations, but these apply only to development planning and aid delivery mechanisms and not to trade (Gender Matters 2013). Although concerns about women issues in poverty alleviation are present in the EU's development policy, these are not translated into Trade policy, despite seeking coherence with development policies. To some extent DG Trade's concern with sustainability, especially regarding labour standards and environmental consequences includes women, however, no specific references to equality are made, making it easy for specific issues to fall off the negotiation agenda.

\section{EU's FTA negotiations with Asian states: the impact of gender absence}

Despite the absence of a gender mainstreaming culture in DG Trade, as the European Commission has associated gender equality with issues of development, there is some generic incorporation of these matters in EU's FTA negotiations with developing and emerging states 
in Asia. All the Sustainability Impact Assessments (SIAs) ${ }^{6}$ for the region take account of gender matters by looking at women education and employment rates, and through UN Human Development Indicators, but this focus on development indicators furthers the development-gender link. The SIA for the EU-South Korea FTA, claims that "no significant adverse effects on gender can be forseen" (IBM Belgium 2008, 15), despite acknowledging that age discrimination at work affects women more than men in Korea (IBM Belgium 2008, 65). More significantly, the final FA with South Korea, for instance, only mentions in Article 22 that the parties "agree to cooperate in the field of employment and social affairs" and that “cooperation may include gender equality" among other issues mentioned. The EU-Korea FA did commit Korea to join the ILO and apply the core conventions. This is expected to have an impact on "decent work" and impact all workers, be they men or women (IBM Belgium 2008, 65). The SIA for negotiations with ASEAN, looking at similar indicators as well as the UN Human Development Indicators highlighted that with the exception of Singapore, women suffer more poverty in ASEAN, have lower literacy rates and work mainly in the services sectors and agriculture and that the FTA could result in a worsening of the gender balance in employment (ECORYS 2009a, 117, 123). ${ }^{7}$ In the case of EU-India negotiations, the SIA claims that as the textile sector concentrates a high proportion of women workers in India, and the FTA is likely to result in increased exports to Europe, the effect will be more jobs for women (ECORYS 2009b, 164). However, the SIA recognises that the overall impact on existing gender inequalities in high-skilled jobs will be negligible (ECORYS 2009b, 294). It merely suggests technical assistance to support Indian productivity and support for India's own programmes in favour of education, training and employment for the low-skilled and low-skilled women (ECORYS 2009b, 396). As negotiations with various ASEAN states (Malaysia, Vietnam, Thailand are ongoing) and the texts agreed with Singapore are awaiting signature and not available, it is impossible to determine at the time of writing whether more gender elements will be incorporated in these agreements. What the FTA with Korea has highlighted, however, is the EU's insistence on extending international 'decent work'

\footnotetext{
${ }^{6}$ Since the early 2000s DG Trade commission's independent studies to consider the potential effects of FTAs on the EU and partner states so as to incorporate that knowledge into the negotiations. The Civil Society Dialogue and though the Sustainability Impact Assessments stakeholders', including social actors', interests in the negotiations are fed-into trade policy. Critics argue civil society positions are heard but rarely make it into the actual negotiations with partners (Maes 2009). Moreover, SIAs tend to have a pro-liberalisation bias in-built as they tend to model for positive growth in trade and investment once barriers are removed, and their quantitative methodology overlooks sectors where little data is available (i.e. informal sector, and which may disproportionately affect women) (Sprecht 2009).

${ }^{7}$ In 2007 the EU launched FTA negotiations with ASEAN, but these were abandoned in 2010 and replaced with individual negotiations with the most advanced economies in ASEAN.
} 
standards of the ILO, and the absence of specific gender clauses or even the reliance on CEDAW (the Convention on the Elimination of All Forms of Discrimination Against Women) (True 2009). Thus, in a case of competing cross-cutting issues, it is clear that the EU has prioritised 'decent work' for its trade negotiations.

Extending compliance with international agreements on labour (ILO) and environmental standards has been a particular normative goal supported by the European Parliament (EP) in an attempt to achieve coherence between internal and external policy making. It also represents a way to articulate the neo-liberal project with the Human and social rights framework (True 2009). The ILO standards are particularly relevant to the gender norms agenda setting because they include the principles of non-discrimination on ground of sex (ILO Convention 111) and equal pay for men and women (ILO Convention 100) as well as being relevant to women who more often than men hold insecure and precarious employment conditions. Since the entry into force of the Lisbon Treaty, the EP has become more involved in oversight of the European Commission whilst it undertakes negotiations with third parties, enhancing its leverage in getting its position taken into account in the negotiations. In a Resolution dated 11 May 2011 on negotiations with India, the EP argued in favour of the inclusion of "legally binding clauses on human rights, social and environmental standards and their enforcement, with measures in the event of infringement" (EP 2011), a view reiterated by the European Economic and Social Committee (2011). The European Commission and Member States share these priorities, which successfully appear in the Framework Agreements that accompany the FTAs with South Korea, Central America, Peru and Colombia (European Union 2010a, 2012a, 2012b).

Commitments to social and environmental clauses notwithstanding, the EU has been criticised for insisting on 'deep' trade $^{8}$ negotiations with developing states, and in particular for the inclusion of services liberalisation in negotiations. From a gender perspective the incorporation of these matters in FTAs with Asia has been considered particularly worrying. Ranja Sengupta and Narendra Jena (2009) argue that liberalisation of health services could lead to pricing-out vulnerable sectors, especially low-income women, and to a loss of qualified health and care personnel in India, if the liberalisation in labour movement for

\footnotetext{
8 'Deep' trade refers to the incorporation of issues in trade relations that go well-beyond traditional matters of tariffs and quotas as restrictions to trade, and include the harmonisation of partners' phytosanitary measures and various standards, intellectual property rights, competition policy, liberalising the rules for service provision (including movement of people), and opening access to public procurement markets.
} 
service provision that India is pushing for is included in the FTA. Women in Development Europe (WIDE) warn of constraint policy space as result of the inclusion of services and public procurement in the negotiations which may hinder India's government's possibilities of using policies to empower vulnerable social groups (Paulus 2009, 8, Wichterich and Menon-Sen 2009). WIDE's overarching criticism is that in separating negotiations of social (including gender) and environmental chapters, these concerns are segregated from the rest of the negotiations and are therefore not mainstreamed into the various trade sectors (Wichterich and Menon-Sen 2009, 37). Significantly, negotiations in other trade sectors may result in damaging outcomes that contradict the very values the EU is trying to protect and promote in the social and environmental chapters. ${ }^{9}$

The underlying irony is that whilst the EU supports normative exports and has mandated itself to actively pursue this in Lisbon under Article 21 TEU, DG Trade's commitment to 'deep' trade (see Young and Peterson 2006), as unequivocally expressed as a warning to other Asian states by Trade Commissioner Karel De Gucht (2010) himself when he announced the launch of FTA negotiations with Singapore: "we are not available to do shallow FTAs," may be hampering the incorporation of that normative agenda into trade policy.

'Global Europe' and 'Trade, Growth and World Affairs' trade policies, designed in the shadow of a blocked WTO Doha Development Round, both focus on pursuing the EU's material interests, and externalising liberalisation as mandated by Article 206 TFEU. The policies prioritise negotiating FTAs with partners with large market potential and higher barriers to EU trade (European Commission 2006, 11), and the liberalisation of services, public procurement markets and regulatory regimes (European Commission 2010, 6). ${ }^{10}$ Various studies argue that without further access to emerging markets in these controversial areas, the EU stands to gain little in economic terms from enhanced relations and FTAs with these (ECORYS 2009a \& b, Decreux et al. 2007). DG Trade's insistence on these matters

\footnotetext{
${ }^{9}$ This is particularly relevant as the different chapter will be negotiated in detail by different officials, possibly form different Ministries. Prior to the creation of the European External Action Service in the Lisbon Treaty, the FAs were negotiated by officials from the Commission's DG Relex, while the FTA part was negotiated by DG Trade. Although the parties' chief negotiators have a global vision of the agreement it is unreasonable to expect them to have every single detail and possible interference of one article with issues elsewhere in the treaty.

${ }^{10}$ Emerging and developing partners have criticised the EU's and USA's insistence on these 'deep' trade matters at the WTO and in FTAs. NGOs and civil society groups have also critiqued the fact that these issues would restrict future policy space, a concern that has also been raised by gender-sensitive critiques of this neoliberal trade model (Sen 2005, Shivpuri 2010),
} 
stems from here, yet, they could, ironically undermine the norm-driven aspects of the EU's Trade and FTA policy.

\section{The external rejection of the EU normative promotion of gender equality}

Reflexivity and norm diffusion are both influential over the way the EU as an external actor (and a self-proclaimed normative leader) is able to shape global gender equality value. As we have seen there is great disparity between the EU's internal rules and its external EU relations with regards to the application of gender equality norms. This lack of reflexivity is compounded by the fact that the EU's actions cannot only be judged on its endeavour to diffuse its fundamental values but also on the level to which these values are adopted (Browning and Christou 2010). Arguably the process is twofold: without the actual import, there is no export of EU values.

Beyond internal inconsistencies, a core difficulty lies in persuading partners to accept the EU's intentional linkage of trade with other norms. Europe's developing and emerging partners have protested the inclusion of sustainability and environmental clauses in negotiations. India has objected to their inclusion in the FTA, as it sees these as a form of European protectionism (Paulus 2009, 7), which is consistent with the widely held perspective in India that the EU is a "protectionist club" (Lisbonne de Vergeron 2006, 25). For example, Indian small and medium producers may struggle to comply with EU environmental certification requirements and sanitary and phytosanitary standards for imports, and critics argue that EU requirements tend to benefit larger firms and agricultural producers (Wichterich 2009, 17).

In terms of social clauses, trade unions from around the world affiliated to the International Trade Union Confederation are strong supporters of EU core values inclusion in FTAs, however, other civil society groups question their usefulness. Naila Kabeer (2004) fears that enforcement of labour standards through trade sanctions could increase labour market inequalities through a shift of jobs towards the informal sector where those labour-standards would not be applied and lead to fewer women in employment. Likewise, Kevin Kolben's (2006) analysis of the issue in India, found wide-spread opposition to the inclusion of labour standards in FTAs across government and civil society members (excepting trade unions) as they were feared that their effect would be to protect Western markets from cheap goods, 
thereby adversely affecting trade and employment in India.

Objections to this comprehensive approach by the EU have been raised in particular by all its Asian partners, a region that has held non-interference in domestic matters as a centre-piece of 'Asian values'. ${ }^{11}$ Thus, even a developed and highly competitive state like Singapore has lengthened FTA negotiations with the EU due to systematic objection to the inclusion of sustainability and environmental clauses in the agreement (Europe World 2010), which could interfere with its domestic policies on these matters. South Korea, too, had important internal debates about the FA, the EP and EU's general FTA/FA approach. ${ }^{12}$ Significantly, when the conclusion of negotiations with Singapore was announced in December 2012 (pending legal team oversight before signing at the time of writing) no announcement was made on the conclusion of the Framework Agreement (FA) that was being negotiated alongside the FTA, which was finalised in June 2013. Prior to this, FTAs and FAs had either been completed simultaneously, or FAs had preceded FTAs, as the EU used the 'carrot' of trade to gain acquiescence for broader regulatory and normative aims in the FAs. Negotiations with Malaysia and Vietnam which were launched in 2010, only entered actual negotiations in late 2012 (DG Trade 2013) again due to differences over the EU's mandated comprehensive approach to FTAs, covering WTO-plus liberalisation, ${ }^{13}$ as well as sustainability and environmental matters (Malaysia Digest 2011).

The case of negotiations with India represents this fundamental objection even more clearly. As a democratic state India shares many of the EU's values, which should facilitate agreement in these matters. However, as Nivedita Sen and Balu Nair $(2011,434)$ argue in reference to the incorporation of human rights (including social and labour rights) in FTAs, India "is of the opinion that such an issue does not belong in a market opening agreement". In the first round of EU-India negotiations in 2007 the issue of human rights was not raised (Business Standard India 6.7.2007), but the EU subsequently incorporated the issue, as part of its global approach to FTAs, and as result of domestic pressure by civil society citing

\footnotetext{
11 'Asian values' refer to Asian doctrines of developmentalism based on Confucian communitarian values, rejection of Western liberal democracy and foreign interference in domestic affairs. For a summary of the debates around the concept see Thompson 2001.

${ }^{12}$ From authors' discussions with Korean trade official.

${ }^{13}$ WTO-plus liberalisation refers to the inclusion in bilateral or plurilateral agreements of issues that are not being negotiated in the WTO Doha Round, in particular competition policy, intellectual property rights, government procurement and services. Attempts by the EU and USA to include these in the WTO negotiations were blocked by emerging states, and were withdrawn from the agenda after the collapse of negotiations at the 2003 WTO Cancún Ministerial Meeting.
} 
labour abuses in India (EU, 2010b). Fears have been expressed in India that as a consequence of the European Parliament's greater trade supervisory powers since the Treaty of Lisbon, there is no certainty that human rights will not be used as a trade weapon by the EU (Business Standard India 13.4.2010). ${ }^{14}$ However, the EU's soft law approach to these issues, as in the enforcement mechanism of the EU-Korea FTA which is through cooperation, and expert panel advice, is unlikely to result in the aggressive stance feared by Indian and other Asian partners (Sen and Nair 2011, 435). This notwithstanding, Asian partners perceive the EU's comprehensive approach as domineering and intrusive, and the EU as a mighty trade competitor whose normative projection could hamper punctual economic interests of partners.

Ultimately, whilst the gender-development nexus has been established within the EU, the gender-trade nexus is largely absent. Instead, it has collapsed into the labour aspects of the concept of sustainability in trade relations. More importantly, with weak enforcement mechanisms in FAs for the non-trade matters negotiated alongside market opening in FTAs, normative extension through FAs and FTAs will remain limited, especially as long as partner states systematically oppose the linking of trade and normative issues. OECD partners such as Canada, Australia and New Zealand are likewise reluctant to sign FAs that may affect trade agreements with the EU. ${ }^{15}$ As the EU embarks on negotiations with the USA a similar situation is likely to arise, further limiting the EU's future ability to link the trade incentive in exchange for normative export in other parts of the world. ${ }^{16}$

\section{Conclusion}

The narrative reveals that the EU has developed strong gender equality legal obligations framed in constitutional and fundamental terms. Moreover, the EU is unambiguously politically and legally committed to achieving gender equality in its internal order and its external actions via the process of gender mainstreaming. This is clearly visible in both the EU's legal obligations and the rhetoric displayed in co-operation and development policy documents. However, when considering the EU's trade policy, explicit references to equality

\footnotetext{
${ }^{14}$ EU-India negotiations have been mired by different economic interests of the parties (see Khorana and Perdikis 2010, Khandekar 2012, Modwel and Singh 2012, Khorana and Garcia 2013).

${ }^{15}$ From authors' discussions with trade officials.

${ }^{16}$ Furthermore, as McGuire and Lindeque (2010) argue, the greater economic relevance of emerging markets is also lessening the EU's potential for exploiting the attraction of its market.
} 
are conspicuous for their absence. Arguably, the prospect of access to key rising markets weakens the EU engagement to achieve gender equality by creating a compromise between economic gain and fundamental value. This is compounded by the absence of gender mainstreaming, which is otherwise used as the main method to export the EU value of gender equality (e.g. in development policy).

The rejection of EU gender equality values (as well as other human and social rights) from the Asian region contributes to the further weakening of the EU's ability to implement gender equality through its broader social sustainability principles. A fundamental problem lies in the fact that other actors in Asia regard this normative insistence as a protectionist reflex on the EU's part. Even states with similar social standards to the EU reject its legalistic approach in linking of these matters to trade agreements. It is, thus, not always a case of rejection of the values per se, but of the EU's mechanism for their extension via conditionality clauses in its Framework Agreements with applicability to the FTAs.

The nature of the EU as a normative power relies on the soft advocacy of Human rights and democratisation. These values are at the core of the EU historical and fundamental raison d'être. The consequence of compromising these values for economic gain is serious on many levels. Indeed, the EU's economic power is supposed to serve as a springboard for diffusing fundamental and democratic values to third countries (Manners 2002, McCormick 2007). David and Guerrina $(2013,56)$ therefore ponder rightfully the logic of the EU: "If norms are the cart, economic power is the horse. The question is, has the EU put the cart before the horse?" The EU genderless external trade relations send a negative message about the EU priorities. Moreover, the concession on fundamental norm-setting and the lack of coherence between the internal and the external EU actions also impacts on the EU's identity building (Bain and Masselot 2013), arguably creating a “double identity” (Stratigaki 2004, 5).

The EU's inability or unwillingness to implement the general principle of gender equality through international actions creates a lack of reflexivity, which in turn compromises the EU as a gender actor, as an international normative power. The inconsistencies between the EU internal and external value norms create an overall watering down of the internal (universal) value and precipitate the retrenchment of well-established fundamental values. This in turns provides space for increasing internal challenges (David and Guerrina 2013). It also opens up further pockets of resistance or rejection in other area of EU external actions, for instance in 
cooperation and development. Already, we note a seriously weak standard for gender equality norms in cooperation and development in the Asian region (Masselot 2013) which only parallels the absence of core EU value in external trade policies in the same region. It further encourages countries which normally would be more willing to accept EU values to reject them. Ultimately, these challenges and resistance pose the question of the credibility and the global reputation of the EU (Schimmelfennig 2001), casting serious doubts about the EU's international "actorness" abilities and, more seriously perhaps, failing to serve women in Asia.

\section{References}

Abdewal, R., and Meunier, S. (2010) "Managed globalisation: doctrine, practice and promise" Journal of European Public Policy, 17(3), 350-367.

Aggestam, L. (2008) “Introduction: ethical power Europe?” International Affairs, 84(1), 111 .

Allwood, G., Guerrina, R., MacRae H. (2013) "Unintended consequences of EU policies: Reintegrating gender in European Studies" Women's Studies International Forum. 39, 1-2.

Allwood, G. (2013) "Gender Mainstreaming and Policy Coherence for Development: Unintended Gender Consequences and EU Policy" Women's Studies International Forum. 39, $42-52$

Arnull, A. (1990) General Principles of EC Law and the Individuals, Leicester: Leicester University Press

Arts, K. (2006) "Gender in ACP-EU Relations: The Cotonou Agreement." In M. Lister and M. Carbone (eds) New Pathways in International Development, Aldershot: Ashgate, 3143.

Bain J. and A. Masselot, (2013) "Gender Equality Law and Identity Building for Europe" Canterbury Law Review 18, 99-120.

Baldwin, M. (2006) "EU Trade Politics - Heaven or Hell?" Journal of European Public Policy, 13(6), 926-942.

Bell, M. "The Principle of Equal treatment: Widening and Deepening" In: P Craig and G. De Búrca (eds) The Evolution of EU Law (second edition), (Oxford University Press, Oxford, 2011) 611-639 at 629.

Browning, C. And Christou, G. (2010) "The Constitutive Power of Outsiders: The European 
Neighbourhood Policy and the Eastern Dimension" Political Geography, 29(2), 109-118.

Business Standard India (2007) "EU May Not Put Human Rights Condition for FTA" 06.07.2007, available at http://bilaterals.org/spip.php?article8925

Business Standard India (2010) "Hope Floats for EU-India Free Trade Pact Talks" 13.04.2010, available at http://www.business-standard.com/india/news/hope-floats-for-indiaeu-free-trade-pact-talks/391740/

David, M. and Guerrina R. (2013) "Gender and European external relations: Dominant discourse and unintended consequences of gender mainstreaming" Women's Studies International Forum. 39, 53-62.

De Bieve, D. and Dür, A., (2005) "Constituency Interests and Delegation in EU and American Trade Policy" Comparative Political Studies, 38/ 10: 1271-1296.

Debusscher, P. \& True, J. (2008) "Lobbying the EU for Gender Equal Development" in J. Orbie and L- Tortell (eds.) The European Union and the Social Dimension of Globalisation, NY, Routledge, 186-206.

Decreux, Y. \& Mitaritonna, C. (2007) Economic Impact of a Potential Free Trade Agreement between the European Union and India, Paris, Report by CEPII CIREM for DG Trade

De Gucht, K. (2010) "Speech: Europe and Singapore: partners in trade, partners for growth" Lee Kuan Yew School of Public Policy, Singapore, 3 March 2010. Available at <http: //europa.eu/rapid/pressReleasesAction.do?reference=SPEECH/10/58>

Derichs, C. (2013) "Gender and Transition in Southeast Asia: Conceptual Travel?" Asia Europe Journal 11, 113-127.

DG Trade (2013) "European Commission Trade with ASEAN Website" http://ec.europa.eu/trade/policy/countries-and-regions/regions/asean/

Docksey, C. (1991) "The Principle of the Equality between Women and Men as a Fundamental Right under Community Law" Industrial Law Journal 20 at 258.

Dür, A., (2008) "Bringing Economic Interests Back into the Study of EU Trade Policymaking” British Journal of Politics and International Relations, 10(1), 27-45.

Eberhardt, P. \& Kumar, D. (2010) Trade Invaders. How big business is driving the EU-India free trade negotiations, Brussels, Corporate Europe Observatory.

ECORYS (2009a) Trade Sustainability Impact Assessment for the FTA between the EU and ASEAN, Report for DG Trade, TRADE07/C1/C01 Lot 2.

ECORYS (2009b) Trade Sustainability Impact Assessment for the FTA between the EU and the Republic of India, Report for DG Trade in the European Commission, TRADE07/C1/C01 - Lot 1.

European Economic and Social Committee (2011) Opinion of the European Economic and 
Social Committee on The role of civil society in the free trade agreement between the EU and India, REX/316, Brussels, 27.10.2011.

Elsig, M. (2007) "The EU's Choice of Regulatory Venues for Trade Negotiations: A Tale of Agency Power?” Journal of Common Market Studies, 45:4, 927-948.

European Commission (2011) Strategy for Equality between Women and Men (2010-2015), Luxembourg: Publication Office of the European Union

European Commission (2010) Growth, Jobs and Trade, COM (2010)216.

European Commission (2006) Global Europe: Competing in the World, COM 567/2006.

European Commission, Communication from the Commission - A Roadmap for Equality between Women and Men (2006 - 2010), COM(2006) 92 Final, 1/3/2006.

European Commission, Communication "Europe and Asia: Strategic Framework for Enhanced Partnerships”, COM(2001) 469 final, 4/9/2001.

European Commission, Communication "Towards A New Asia Strategy", COM(94) 314 final, 13/7/1994.

European Parliament (2011) Resolution on the State of Play in the EU-India Free Trade Agreement Negotiations, 11.05.2011, Strasbourg, N. P7_TA_PROV (2011) 0224.

European Union (2010a) Framework Agreement between the European Union and its Member States and the Republic of Korea.

European Union (2010b) "EU India Relations Background Note. Press Release”, 21.06.2010, available http://europa.eu/rapid/pressReleasesAction.do?reference=MEMO/10/265\&type=HTML

European Union (2012a) Association Agreement between the European Union and its Member States and Central America.

European Union (2012b) Association Agreement between the European Union and its Member States and the Republic of Peru and Republic of Colombia.

Europe World (2010) "Big Prospects for Upcoming EU-Singapore FTA" 5 Nov 2010 Available http://www.europesworld.org/NewEnglish/Home_old/CommunityPosts/tabid/809/PostID/197 5/language/en-US/Default.aspx, (Accessed 20.01.2012)

Garcia, M. (2012) "The European Union and Latin America: 'Transformative Power Europe' versus the Realities of Economic Interests" Cambridge Review of International Affairs, OnlineFirst.

Garcia, M. (2013) "From Idealism to Realism: EU Preferential Trade Agreement Policy" Journal of Contemporary European Research, 9(3). 
Gender Matters (2013) "UN/EU Partnership on Gender Equality in Development and Peace Website", http://www.gendermatters.eu/

Horn, H., Mavroidis, P. \& Sapir, A. (2010) "Beyond the WTO? An Anatomy of EU and US Preferential Trade Agreements" The World Economy, 33(11), 1565-1588.

Hoskyns, C. (1996) Integrating gender: Women, Law and Politics in the European Union, London: Verso.

Hoskyns, C. (2004) "Mainstreaming Gender in the Macroeconomic Policies of the EU Institutional and Conceptual Issues" Paper presented at the ECPR conference, Bologna June 2004, http://www.jhubc.it/ecpr-bologna/docs/179.pdf

IBM Belgium (2008) Trade Sustainability Impact Assessment of EU-Korea FTA: Draft Final Report, Prepared for DG Trade.

Kaber, Naila (2004) "Globalisation, Labour Standards and Women's Rights: Dilemmas of Collective (in) Action in an Interdependent World" Feminist Economics, 10(1), 3-35.

Khandekar, G. (2012) "The EU-India Summit: on the threshold of change" ESP Policy Brief No. 1, European Strategic Partnerships Observatory, FRIDE, Egmont.

Khorana, S. \& Perdikis, N. (2010) "EU and India Free Trade Agreement: Deal or No Deal?" South Asia Economic Journal, 11(2), 181-206.

Khorana, S. and Garcia, M. (2013) "EU-India Free Trade Agreement Negotiations: One Step Forwards, One Step Back” Journal of Common Market Studies, (2), 684-700.

Kolben, K. (2006) "The New Politics of Linkage: India"s Opposition to the Workers' Rights Clause" Indiana Journal of Global Legal Studies, Vol. 13, pp. 225-258.

Koukoulis-Spiliotopoulos, S. "The Lisbon Treaty and the Charter of Fundamental Rights: Maintaining and Developing the aquis in Gender Equality" (2008), European Gender Equality Law Review, 1, 15-24.

Lightfoot, S. and Burchell, J. (2005) "The European Union at the World Summit on Sustainable Development: Normative Power Europe in Action" Journal of Common Market Studies, 43(1), 75-95.

Lisbonne de Vergeron, K. (2006) Contemporary Indian Views of Europe, London, RIIA Chatham House.

MacRae, H. (2013) "(Re-)Gendering integration: Unintended and unanticipated gender outcomes of the European Union policy” Women's Studies International Forum. 39, 3-11.

Maes, M. (2009) "Civil Society Perspectives on EU-Asia Free Trade Agreements" Asia Europe Journal, 7, 97-107.

Malaysia Digest "Fifth Round of EU-Malaysia Negotiations" 30 Sept 2011 Available at: http://malaysiandigest.com/business/32357-fifth-round-fta-negotiations-between-malaysia- 
eu-in-mid-oct.html, (Accessed 20.01.2012).

Manners, I. (2008) "The normative ethics of the European Union" International Affairs, $84(1), 45-60$.

Manners, I. (2002), "Normative Power Europe: A Contradiction in Terms?" Journal of Common Market Studies, 40:2 235-258.

Masselot A. (2013) "Does the European Union "Walk the Walk" or Just "Talk the Talk" of Gender Equality in Water Development Projects in the Asian Region?", wH2O: The Journal on Gender and Water, 2, 8-14.

McCormick, J. (2007) The European Superpower, London: Palgrave

McGauran, A. (2009) "Gender mainstreaming and the public policy implementation process: round pegs in square holes?" Policy and Politics, 37(2), 215-233.

McGuire, S. \& Lindeque, J. (2010) "Diminishing Returns to Trade Policy in the European Union” Journal of Common Market Studies, 45(5), 1329-1349.

Meunier, S. (2007) "Managing Globalisation: The EU in International Trade Negotiations" Journal of Common Market Studies, 45(5), 905-926.

Meunier, S. (2000) "What Single Voice? European Institutions and EU-US Trade Negotiations" International Organization, 54(1), 103-135.

Meunier, S. \& Nicolaidis, K. (2006) "The EU as a Conflicted Trade Power" Journal of European Public Policy, 13(6), 906-925.

Meunier, S. and Nicolaidis, K. (1999) "Who Speaks for Europe? The Delegation of Trade Authority in the EU" Journal of Common Market Studies, 37(3), 477-510.

Michell, T. (2003) "The Middle East in the Past and Future of Social Sciences" University of California International and Areas Studies Digital Collection, The politic of knowledge: Area Studies and the Disciplines, 3 (University of California Press, Berkey).

Modwel, S. \& Singh, S. (2012) "The EU-India FTA Negotiations: Leading to an Agreement or Disagreement?” ORF Occasional Paper No. 32, Observer Research Foundation.

Paulus, L. (2009) "The EU-India Free Trade Agreement negotiations: Gender and social justice concerns. A memo for Members of the European Parliament" Brussels, WIDE. Available at http://www.wide-network.org (Accessed 01.07.2013)

Pollack, M. and E. Hafner-Burton, "Mainstreaming gender in the European Union" (2000), Journal of European Public Policy, 7(3), 432-56.

Schimmelfennig, F. (2001) "The Community Trap: Liberal Norms, Rhetorical Actions, and the Eastern Enlargement of the European Union" International Organization, 55(1), 47-80. 
Sen, Gita (2005) "Neolibs, Neocons and Gender Justice: Lessons from Global Negotiations" Occasional Paper No 9, United Nations Research Institute for Social Development.

Sen, N. and Nair, B. G. (2011) "Human Rights Provisions in the forthcoming India-EU Free Trade Agreement" NUJS Law Review, 4, 417-437.

Sengupta, R. and J., Narendra (2009) "The Current Trade Paradigm and Women's Health Concerns in India: With Special Reference to the Proposed EU-India Free Trade Agreement" Centre for Trade and Development and Heinrich Boell Foundation, New Dehli www.boellindia.org/web/112-534.html

Shivpuri, A. (2010) "Towards a gender-sensitive trade regime" Trade Policy Analysis, Issue Paper, November 2010, South Asia Watch on Trade, Economics and Environment, SAWTEE, www.sawtee.org

Smith, M. (2006) "The EU as an International Actor" In Richardson, J. (ed.) European Union: Power and Policy-Making, Abingdon, Routledge, 289-310.

Sprecht, B. (2009) "A critical review of the Trade Sustainability Impact Assessment for the Free Trade Agreement between the EU and the Republic of India from a gender perspective" WIDE Network, Brussels www.wide-network.org

Stratigaki, M. (2004) "The Cooptation of Gender Concepts in EU Policies: The Case of "Reconciliation of Work and Family" Social Politics: International Studies in Gender, State and Society, 11(1), 30-56.

Thompson, M. R. (2001) "Whatever Happened to “Asian Values"?" (2001) Journal of Democracy, 12(4), 154-165.

True, J. (2009) "Trading-in gender equality: Gender meanings in EU trade policy" in Lombardo, E., Meier, P. and Verloo, M. (eds) The Discursive Politics of Gender Equality: Stretching, Banding and Policy-Making, Routledge.

United Nation (2013) UN ESCAP Annual report 2013, Bangkok: United Nation Publication http://issuu.com/escap-publications/docs/escap-annual-report-

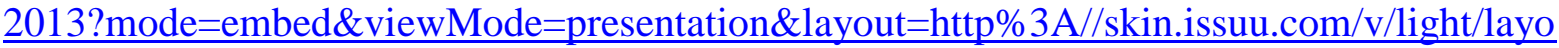
ut.xml

Vogler, J. and Stephen, H. "The European Union in Global Environmental Governance: Leadership in the Making?" (2007), International Environment Agreements, 7, 389-413.

Wichetrich, C. (2009) “Trade-A Driving Force for Jobs and Women's Empowerment? Focus on China and India" FES Briefing paper 7 , WIDE-Network.

Wichterich, C. (2008) "Fierce, Fair and Unfair Competition. The EU-China Trade Race and its Gender Implications" WIDE-Network, Brussels, www.wide-network.org

Wichterich, C. (2007) "Economic Growth without Social Justice. EU-India Trade Negotiations and their Implications for Social Development and Gender Justice" WIDENetwork, Brussels www.wide-network.org 
Wichterich, C. and Menon-Sen, K. (2009) "Trade Liberalisation, Gender Equality, Policy Space: The Case of the Contested EU-India FTA" WIDE-Network www.wide-network.org

Woolcock, S. (2007) “European Union policy towards FTAs” ECIPE Working Paper 3/2007.

Young, A \& Peterson, J. (2006) "The EU and New Trade Politics" Journal of European Public Policy, 13(6), 795-814.

Youngs, R. (2004) "Normative Dynamics and Strategic Interests in the EU's External Identity” Journal of Common Market Studies, 43 (4) 787-806. 